\title{
Lernaea (Anchorworm) Infestations in Fish ${ }^{1}$
}

\author{
Natalie Steckler and Roy P. E. Yanong ${ }^{2}$
}

\section{Introduction}

Lernaea species, commonly known as "anchorworms," are crustacean, copepod parasites that can infect and cause disease and mortality in many types of freshwater fishes, especially wild-caught and pond-raised species. Infestations with Lernaea are most prevalent in the summer months and occur more commonly in stagnant or slow-moving water bodies.

Approximately 110 species of lernaeids (Lernaea and Lernaea-like parasites) have been described. Lernaea cyprinacea, one of the more common species, is found worldwide. It is most common in cyprinids, including koi, common carp, and goldfish; however, it can infect other species of fish and has caused major kills in Arkansas catfish in ponds that were also stocked with bighead carp. Lernaea has also been reported to infest amphibians.

\section{Life Cycle of Lernaea}

Because Lernaea is a copepod and crustacean, it is related to crabs, lobsters, and shrimp, all of which have a multistage life cycle (Figure 1). Lernaea is unusual, however, as most common copepod species are free-living and do not cause disease. Although organisms belonging to this group have complex life cycles, they do not need to pass through an intermediate host; rather they can spread directly from fish to fish. This direct life cycle can take from 18 to 25 days to complete, and only a fish (or an amphibian) is necessary for the organism to develop from egg to mature adult.
The lernaeid life cycle is similar whether the host is a fish or amphibian, but for simplicity this paper will focus on infections in fish.

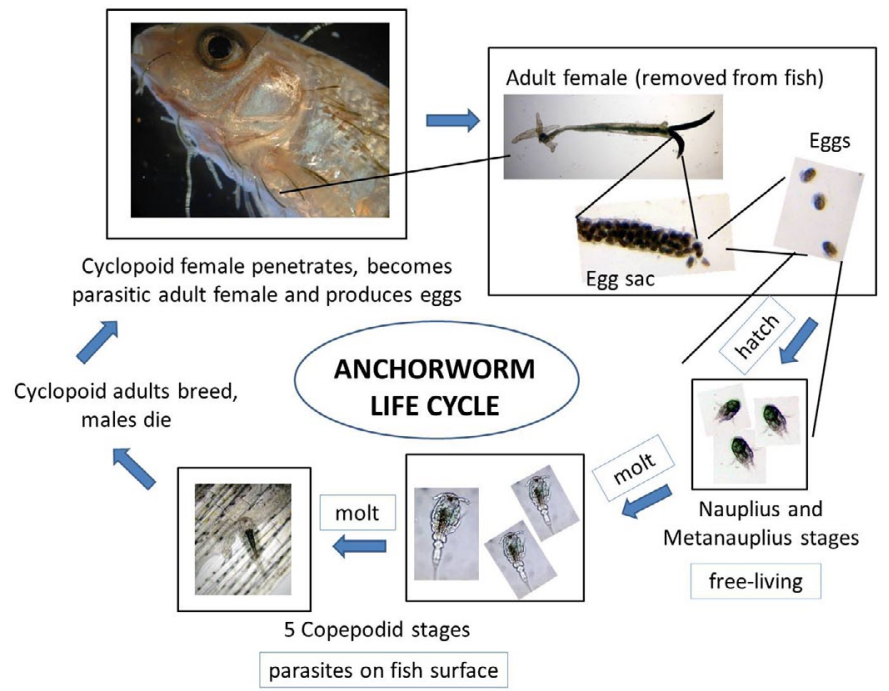

Figure 1. Lernaea (anchorworm) life cycle. The entire life cycle may take from $18-25$ days at approximately $25-30^{\circ} \mathrm{C}$.

Credits: Tropical Aquaculture Laboratory

Different life stages during development live on and off the fish. After a male and female parasite mate, the male dies and the female bores into the host tissue, eventually using a large anchor on her anterior ("head") end to permanently embed into the skin and muscle of the fish (Figure 2). The female matures into an adult and, within 24 hours, may begin to release eggs from a pair of sacs on its posterior

1. This document is FA185, one of a series of the Program in Fisheries and Aquatic Sciences, School of Forest Resources and Conservation, Florida Cooperative Extension Service, Institute of Food and Agricultural Sciences, University of Florida. Original publication date December 2012. Visit the EDIS website at http://edis.ifas.ufl.edu.

2. Natalie Steckler, graduate student, Program in Fisheries and Aquatic Sciences, School of Forest Resources and Conservation; and Roy P. E. Yanong, associate professor and Extension veterinarian,Tropical Aquaculture Laboratory, Program in Fisheries and Aquatic Sciences, School of Forest Resources and Conservation, Ruskin, FI 33570. 
("back") end (Figure 3). Each released egg hatches within 24-36 hours. Females are very prolific, and can produce batches of up to 250 juveniles (nauplii) every two weeks for up to 16 weeks at temperatures warmer than $25^{\circ} \mathrm{C}$.

Newly hatched nauplii are free-living (not parasitic) and develop through three different naupliar stages in about 4 days. At that point they molt into the first copepodid stage, become parasitic, and attach to a host, often on the gills. Over the next 7 days, the parasite develops through five different "copepodid" stages. The copepodid stages typically are also found on the gills but are not permanently embedded in the tissue. Once in the final copepodid stage, the male detaches, but the female remains parasitic, attached to the current host or moving to another fish. Adult males die within 24 hours. In one study, the entire life cycle took approximately $18-25$ days when fish were held at $29^{\circ} \mathrm{C}$.

The optimal temperature range for Lernaea is $26-28^{\circ} \mathrm{C}$. If temperatures fall below $20^{\circ} \mathrm{C}$, juvenile Lernaea are unable to complete their development, and at $14^{\circ} \mathrm{C}$, females will not reproduce. However, adult females can overwinter on the fish host, producing eggs when water temperatures warm up in the spring.

\section{Disease in Fish Caused by Lernaea}

Common sites of Lernaea infections include the skin, fins, gills, and oral cavity (Figure 2). Large numbers of lernaeids in copepodid stages can kill small fish by damaging their gills and making it hard for the fish to breathe. When female parasites attach to the fish, they burrow deep into the tissues and eventually embed an anterior anchor into the fish's body. Intense focal inflammation and hemorrhage can occur at the attachment site, making the area appear red and ulcerated.

While an infection by small numbers of parasites isn't necessarily fatal, it is extremely irritating to the fish.

Lernaea can cause intense inflammation, leading to secondary bacterial (e.g., Aeromonas hydrophila) and fungal infections. These secondary infections sometimes worsen and kill the fish. Larger numbers of parasites on the gill can interfere with respiration, causing death. Fish can survive Lernaea infection, but chronic conditions frequently result in poor growth and body condition.

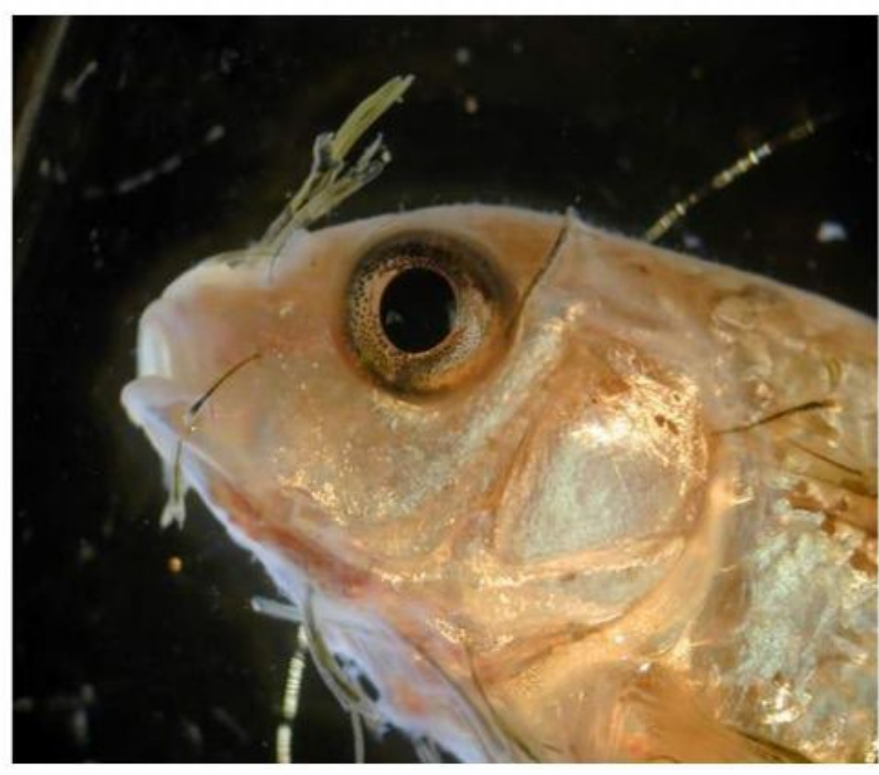

Figure 2. Koi infested with numerous female Lernaea Credits: Tropical Aquaculture Laboratory

\section{Diagnosis}

When seen by the naked eye, the most commonly observed life stage of the organism - the adult female-appears as a small, thin "thread" or "hair" approximately $25 \mathrm{~mm}$ long. Under the microscope, the long, tubular body has an anchor on the anterior end and paired egg sacs on the posterior end (Figure 3). The anchor, located in the anterior ("head") region, is typically embedded into the host's tissue, while the posterior end, with its egg sacs, extends out into the water column. Juvenile life stages, especially the copepodid stages, may also be seen on skin, fin, or gill samples with use of a microscope (Figure 1). Because adult female Lernaea may be confused with plant fibers, fungi, or other organisms, a fish health professional should be consulted for an accurate diagnosis. Use of a microscope to examine wet mounts of affected areas (skin, gill, oral cavity, fins) will be necessary to confirm the presence of this parasite.

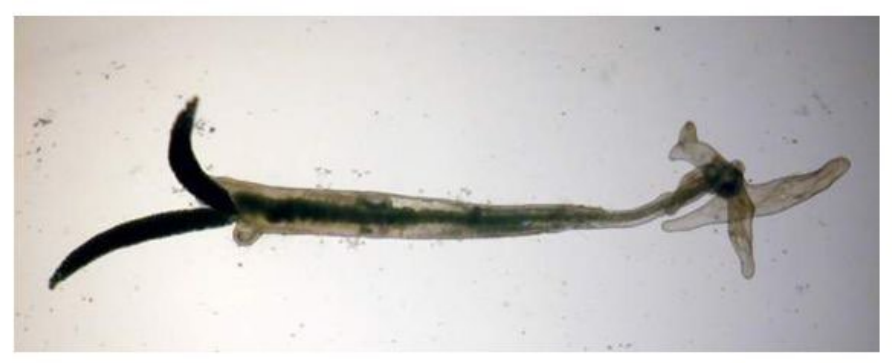

Figure 3. Adult female, removed from fish. Note "anchor" on right, which embeds into the fish, and paired egg sacs on left. Credits: Tropical Aquaculture Laboratory 


\section{Management}

Individual lernaeids can be removed from the affected fish using forceps. However, the removal is not always complete; sometimes the anchor portion remains embedded. The forceps method is impractical on a large scale, and other methods are recommended. Regardless of the method used, treatment of the entire system is necessary in order to treat all the fish and to control all life stages of the parasite, including those stages that survive off the host. Adult female lernaeids can survive 30 days on a fish host and are hardier than younger life stages; therefore, treatment should continue for several weeks.

A number of methods have been used effectively to control Lernaea, but recommendations will vary depending upon the fish species and the situation. Consultation with a fish health professional is necessary to ensure legal and appropriate drug or pesticide use. It should be noted that the only available treatment regimen for Lernaea in food fish species is salt. Salt has been researched as a treatment for Lernaea with variable results. In one salinity study with L. cyprinacea, a percentage of adult females survived fairly prolonged exposure, up to $22.4 \mathrm{~g} / \mathrm{L}$ seawater (ppt) for up to 6 days. At $25.6 \mathrm{ppt}$, adults were killed by day 2 . On the other hand, hatching of lernaeid eggs did not occur at 8 $\mathrm{g} / \mathrm{L}$ seawater, and development of younger life stages that did hatch was prevented if the parasites were exposed for at least 5-6 days at $4.8 \mathrm{~g} / \mathrm{L}$. For food fish that can tolerate the salinity, $4.8 \mathrm{~g} / \mathrm{L}$ seawater for up to about 30 days is the best choice to control the parasite because other drugs and pesticides are not legal for treatment of food fish species. Because adult female lernaeids are more tolerant of salt, additional measures may be necessary to effectively break the parasite life cycle. Removing fish from the system for 7 days will break the life cycle in the tank because larval stages cannot survive without a host for this time period.

For non-food fish species, such as ornamental production or home aquarium situations, additional treatments besides salt are available. Prolonged immersion with an organophosphate such as trichlorfon is an effective treatment for ornamental fish. A 30 -minute bath with $25 \mathrm{mg} / \mathrm{L}$ potassium permanganate will kill larval lernaeids, but adults may survive. Diflubenzuron (also known as Dimilin) is a pesticide that interferes with growth of the parasite and will kill molting adult and larval stages at a dose of 0.066 mg diflubenzuron/liter. (Again, if the drugs or pesticides described above are not an option, then $4.8 \mathrm{~g} / \mathrm{L}$ seawater for up to about 30 days should help control the parasite as long as the fish can tolerate this salinity level. Fish can also be removed from the system for 7 days to break the lernaeid life cycle within the tank.)

Wounds resulting from an infection with Lernaea should be closely monitored, and optimal water quality should be maintained for the duration of treatment to minimize risk of secondary bacterial and fungal infection. Interestingly, there is evidence suggesting that successfully treated fish may become resistant to future infections with Lernaea.

\section{Prevention}

Incoming fish must be strictly quarantined and tested in order to avoid introducing Lernaea to a system. This is especially important with food fish species because treatment options are so limited. Before they are introduced into a system, all fish, especially high risk species such as carps (e.g., goldfish and koi), should be visually screened for adult parasites and then monitored regularly during quarantine. If the parasite is detected, early intervention will result in the most successful outcome.

\section{Discussion}

Lernaea infestations are particularly common in cyprinids, including koi, goldfish, and other related carp, although numerous other freshwater species are susceptible. Individual parasites can cause severe focal damage to affected tissue, increasing the risk of infection by bacterial and fungal pathogens present in the environment. Several effective therapies are available for control of lernaeids; however, options are very limited for food fish and pond production. Quarantine and screening of incoming fish are highly recommended to avoid introduction of the parasite.

\section{References and Suggested Readings}

Goodwin, A.E. 1999. Massive Lernaea cyprinacea infestations damaging the gills of channel catfish polycultured with bighead carp. Journal of Aquatic Animal Health 11:406-408.

Ho, J.S. 1996. Cladistics of the Lernaeidae (Cyclopoida), a major family of freshwater fish parasites. Journal of Marine Systems 15: 177-183.

Hoffman, G.L. 1999. Parasites of North American freshwater fishes, second ed. Cornell University Press, Ithaca, NY.

Kupferberg, S.J., A. Catenazzi, K. Lunde, A.J. Lind, and W.J. Palen. 2008. Parasitic copepod (Lernaea cyprinacea) 
outbreaks in foothill yellow-legged frogs (Rana boylii) linked to unusually warm summers and amphibian malformations in northern California. Copeia 3: 529-537.

Lester, R.J.G., and C.J. Hayward. 2006. Phylum Arthropoda. In Fish Diseases and Disorders, vol. 1: protozoan and metazoan infections, second ed. P.T.K. Woo, editor. CAB International, London, England. Pp. 466-565.

Longshaw, M., and S.W. Feist. 2001. Parasitic diseases. In BSAVA Manual of Ornamental Fish, second ed. W.H. Wildgoose, editor. British Small Animal Veterinary Association, Gloucester, England. Pp. 167-183.
Noga, E.J. 2010. Fish Disease: Diagnosis and Treatment, second ed. Wiley-Blackwell, Ames, IA.

Shields, R.J. 1978. Procedures for the laboratory rearing of Lernaea cyprinacea L. (Copepoda). Crustaceana 35: 259-264.

Shields, R.J., and R.P. Goode. 1978. Host rejection of Lernaea cyprinacea L. (Copepoda). Crustaceana 35: 301-307. Stoskopf, M.K. 1993. Fish Medicine. W.B. Saunders Company, Philadelphia, PA. 